\title{
WATER QUALITY STUDY IN MORNI TOWN, PANCHKULA DISTRICT, HARYANA, INDIA
}

\author{
Anup Kumar ${ }^{1^{*}}$, Rajesh ${ }^{2}$, Sanjay Kumar ${ }^{2}$ and Gourango Prasad Datta ${ }^{2}$ \\ ${ }^{1}$ Front Office-HARSAC, Panchkula, Haryana, India \\ ${ }^{2}$ Govt. ITI, Panchkula, Haryana, India
}

\begin{abstract}
Water is necessary for survival of living beings. In the modern developmental activities water is one of the natural resource under pressure of anthropogenic activities. In hilly areas it is also polluted due to anthropogenic activities and direct mixing of polluted water with fresh water due to flow of polluted water through joints and fractures. In the present study water quality at Morni town located on Lower Siwalik hill has been studied. Five water samples have been collected during J une 2018 and analysed using field water testing kit prepared by Tamilnadu Water Supply and Drainage Board, Chennai for twelve chemical parameters. The results of chemical analysis of water samples shows that $\mathrm{pH}$ varies 6.5 -7, alkalinity $100 \mathrm{mg} / \mathrm{l}$ to $150 \mathrm{mg} / \mathrm{l}$, hardness $140 \mathrm{mg} / \mathrm{l}$ to $230 \mathrm{mg} / \mathrm{l}$, chloride $20 \mathrm{mg} / \mathrm{l}$ to $50 \mathrm{mg} / \mathrm{l}$, total dissolved solids (TDS) $336 \mathrm{mg} / \mathrm{l}$ to 516 $\mathrm{mg} / \mathrm{l}$, fluoride $0.5 \mathrm{mg} / \mathrm{l}$ to $1.5 \mathrm{mg} / \mathrm{l}$, Iron $0 \mathrm{mg} / \mathrm{l}$ to $10 \mathrm{mg} / \mathrm{l}$, ammonia $0.5 \mathrm{mg} / \mathrm{l}$ to $2.0 \mathrm{mg} / \mathrm{l}$, nitrite $0.2 \mathrm{mg} / \mathrm{l}$ to $0.5 \mathrm{mg} / \mathrm{l}$, nitrate $20 \mathrm{mg} / \mathrm{l}$ to $45 \mathrm{mg} / \mathrm{l}$, phosphate nil in all water samples and residual chlorine $0 \mathrm{mg} / \mathrm{l}$ to $0.5 \mathrm{mg} / \mathrm{l}$. The water quality is potable in three water samples and non-potable in two water samples (Kila Ghat and Handpump-2). The study is useful for monitoring the water quality for drinking purpose.
\end{abstract}

\section{Keywords}

Water, quality, potable, nonpotable, Morni, Haryana.

\section{INTRODUCTION}

Water is prime requirement for survival of living beings. Suitability of water for different uses like drinking, agriculture and industrial purposes mainly depends on its quality. For all the different uses of water for drinking purpose its quality should be as per drinking water standards of Bureau of Indian Standards in India. The availability of good quality water in present context of developmental activities has become rare because of anthropogenic activities in all types of terrain whether plain or hills. Workers have done work on water quality in different types of terrains to understand the water quality status (Goel et al. (2018), Ismail (2015), Oiste (2014), Satyanarayana et al. (2013), Sujatha et al. (2012), Wali et al. (2018)).

\section{Study area}

Morni town is located on Lower Shiwalik Hills in Panchkula district of Haryana. The geo-coordinates of the town is latitude $30.7^{\circ} \mathrm{N}$ and longitude $77.08^{\circ} \mathrm{E}$ and located at an altitude of $1267 \mathrm{~m}$ above mean sea level.

\section{Objective}

The main objective was to study water quality for drinking purpose in Morni town, Panchkula district, Haryana.

\section{MATERIALS AND METHODS}

Total five water samples were collected from different locations in Morni Town in the month of June 2018 in $120 \mathrm{ml}$ plastic bottles. Water samples were analysed using Field Water Testing Kit prepared by Tamilnadu Water Supply and Drainage Board, Chennai for twelve chemical parameters$\mathrm{pH}$, alkalinity, hardness, chloride, total dissolved solids, fluoride, iron, ammonia, nitrite, nitrate, phosphate and residual chlorine (Table 1). Chemical analysis results of water samples were compared with BIS Drinking Water Standards (IS 10500:2012) (Table 2). The chemical analysis results were entered in the excel and prepared bar graphs for each chemical parameter. 
Table1: Water sample analysis results (in mg/l except pH).

\begin{tabular}{|c|c|c|c|c|c|c|c|c|c|c|c|c|c|c|}
\hline $\begin{array}{l}\text { Water } \\
\text { Sample }\end{array}$ & Latitude & Longitude & $\mathrm{pH}$ & Alkalinity & Hardness & Chloride & TDS & Fluoride & Iron & Ammonia & Nitrite & Nitrate & $\begin{array}{l}\text { Phos- } \\
\text { phate }\end{array}$ & $\begin{array}{l}\text { Resi- } \\
\text { dual }\end{array}$ \\
\hline $\begin{array}{l}\text { Kila } \\
\text { Ghat }\end{array}$ & 30.689847 & 77.082847 & 6.5 & 100 & 150 & 30 & 336 & 1.5 & 2 & 0.5 & 0.5 & 20 & 0 & 0.5 \\
\hline $\begin{array}{l}\text { Water } \\
\text { Tank }\end{array}$ & 30.689836 & 77.082807 & 6.5 & 130 & 150 & 30 & 372 & 1 & 0.3 & 0.5 & 0.5 & 45 & 0 & 0 \\
\hline $\begin{array}{l}\text { Hand } \\
\text { pump-1 }\end{array}$ & 30.688037 & 77.086669 & 6.5 & 150 & 200 & 30 & 456 & 1.5 & 1 & 0.5 & 0.2 & 20 & 0 & 0 \\
\hline $\begin{array}{l}\text { Hand-2 } \\
\text { pump }\end{array}$ & 30.686457 & 77.088832 & 7 & 150 & 230 & 50 & 516 & 0.5 & 10 & 2 & 0.5 & 45 & 0 & 0.2 \\
\hline $\begin{array}{l}\text { Jal } \\
\text { Ghar }\end{array}$ & 30.687817 & 77.087525 & 6.5 & 130 & 140 & 20 & 348 & 0.5 & 0 & 0.5 & 0.5 & 20 & 0 & 0 \\
\hline
\end{tabular}

Table 2: Drinking water standards (IS 10500:2012).

\begin{tabular}{|c|c|c|c|c|}
\hline \multirow[t]{2}{*}{ S. No. } & \multirow[t]{2}{*}{ Parameter } & \multicolumn{2}{|c|}{ Potable } & \multirow[t]{2}{*}{ Non-Potable } \\
\hline & & Desirable & Permissible & \\
\hline 1. & $\mathrm{pH}$ & 6.5 to 8.5 & -- & $<6.5$ to $>8.5$ \\
\hline 2. & Total Hardness (mg/l) & $<200$ & $200-600$ & $>600$ \\
\hline 3. & Iron (Fe) (mg/l) & $<0.3$ & -- & $>0.3$ \\
\hline 4. & Chlorides (Cl) (mg/l) & $<250$ & $250-1000$ & $>1000$ \\
\hline 5. & $\begin{array}{l}\text { Total Dissolved Solids } \\
\text { (TDS) (mg/l) }\end{array}$ & $<500$ & $500-2000$ & $>2000$ \\
\hline 6. & Nitrate (NO3) (mg/l) & $<45$ & -- & $>45$ \\
\hline 7. & Fluoride (F) (mg/l) & $<1.0$ & $1.0-1.5$ & $>1.5$ \\
\hline 8. & Residual Chlorine (RC) (mg/l) & $<0.2$ & $0.2-1$ & $>1.0$ \\
\hline 9. & Ammonia (mg/l) & $<0.5$ & -- & $>0.5$ \\
\hline 10. & Alkalinity (mg/l) & $<200$ & $200-600$ & $>600$ \\
\hline 11. & Nitrite (mg/l) & $<1.0 \mathrm{mg} / \mathrm{l}$ & - & $>1.0 \mathrm{mg} / \mathrm{l}$ \\
\hline 12. & Phosphate (mg/l) & $<1.0 \mathrm{mg} / \mathrm{l}$ & - & $>1.0 \mathrm{mg} / \mathrm{l}$ \\
\hline
\end{tabular}

\section{RESULTS AND DISCUSSION}

pH

$\mathrm{pH}$ in the water samples varies 6.5 to 7 . In all the five water samples $\mathrm{pH}$ is desirable as per drinking water standards (Figure 1, Table1 and Table2).

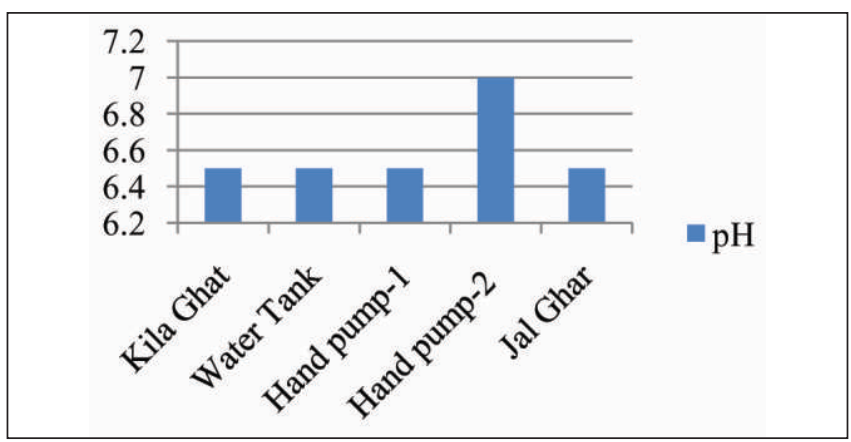

Figure 1: pH in water samples.

\section{Alkalinity}

Alkalinity in the water samples varies $100 \mathrm{mg} / \mathrm{l}$ to $150 \mathrm{mg} / \mathrm{l}$. In all the five water samples alkalinity is desirable category as per drinking water standards (Figure 2, Table1 and Table2).

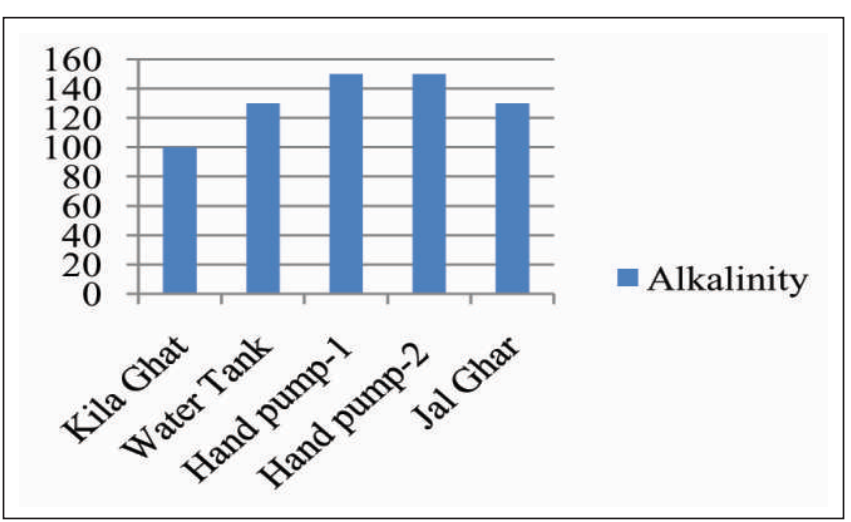

Figure 2: Alkalinity (mg/l) in water samples 


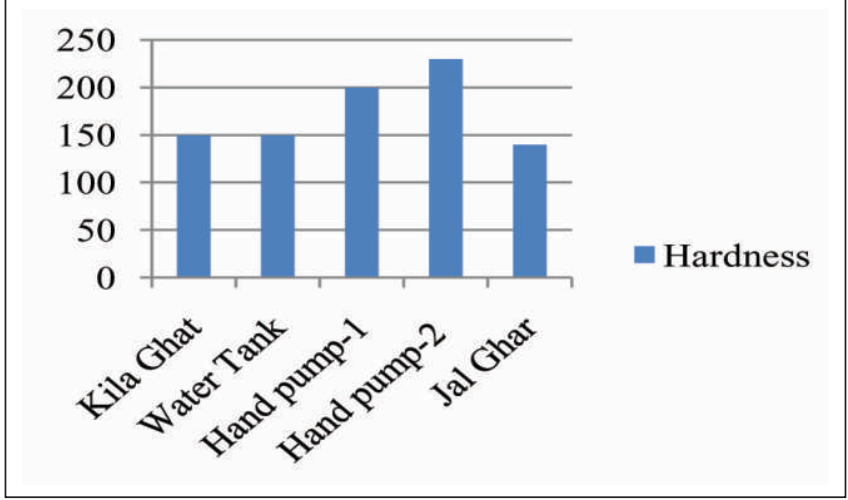

Figure 3: Hardness (mg/l)in water samples.

\section{Hardness}

Hardness in the water samples varies $140 \mathrm{mg} / \mathrm{l}$ to $230 \mathrm{mg} / \mathrm{l}$. In Handpum-2 hardness is permissible (230 mg/l) and in other four water samples hardness is desirable as per drinking water standards (Figure 3, Table1 and Table2).

\section{Chloride}

Chloride in the water samples varies $20 \mathrm{mg} / \mathrm{l}$ to $50 \mathrm{mg} / \mathrm{l}$. In all the five water samples chloride is desirable as per drinking water standards (Figure 4, Table1 and Table2).

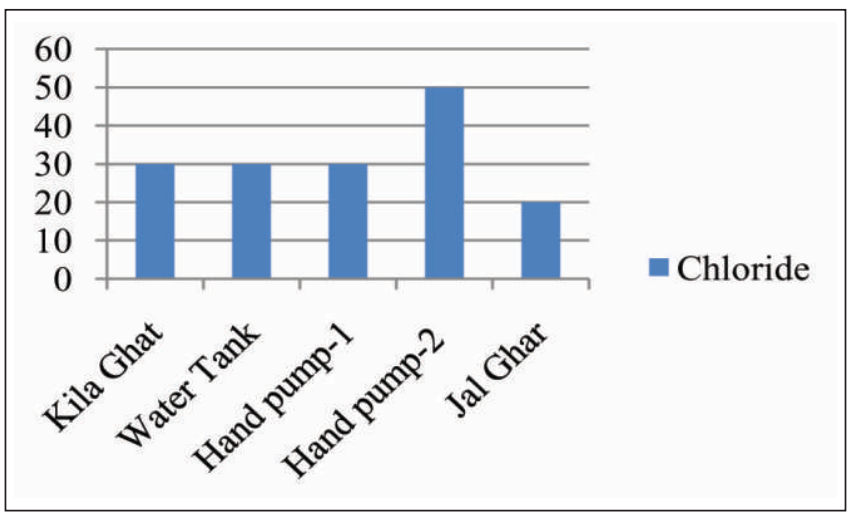

Figure 4: Chloride (mg/l)in water samples.

Total Dissolved Solids (TDS)

Total Dissolved Solids (TDS) in the water samples varies 336 $\mathrm{mg} / \mathrm{l}$ to $516 \mathrm{mg} / \mathrm{l}$. In Handpum-2 TDS is permissible (516 $\mathrm{mg} / \mathrm{l}$ ) and in other four samples Total Dissolved Solids is desirable as per drinking water standards (Figure 5, Table1 and Table2).

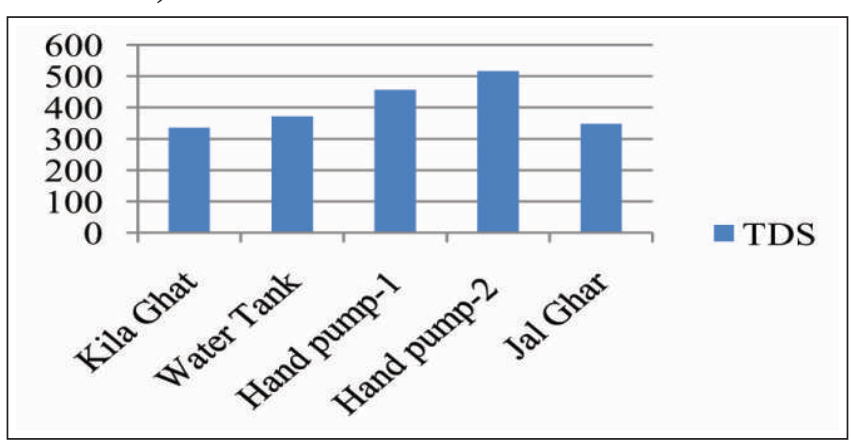

Figure 5: Total Dissolved Solids (TDS) (mg/l) in water samples

\section{Fluoride}

Fluoride in the water samples varies $0.5 \mathrm{mg} / \mathrm{l}$ to $1.5 \mathrm{mg} / \mathrm{l}$. In all the five water samples fluoride is desirable as per drinking water standards (Figure 6, Table1 and Table2).

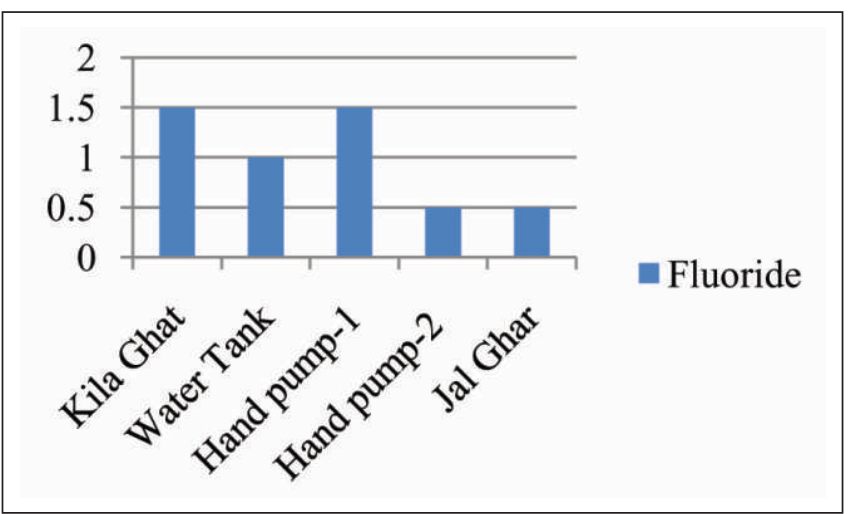

Figure 6: Fluoride (mg/l)in water samples.

Iron

Iron in the water samples varies $0 \mathrm{mg} / \mathrm{l}$ to $10 \mathrm{mg} / \mathrm{l}$. In two

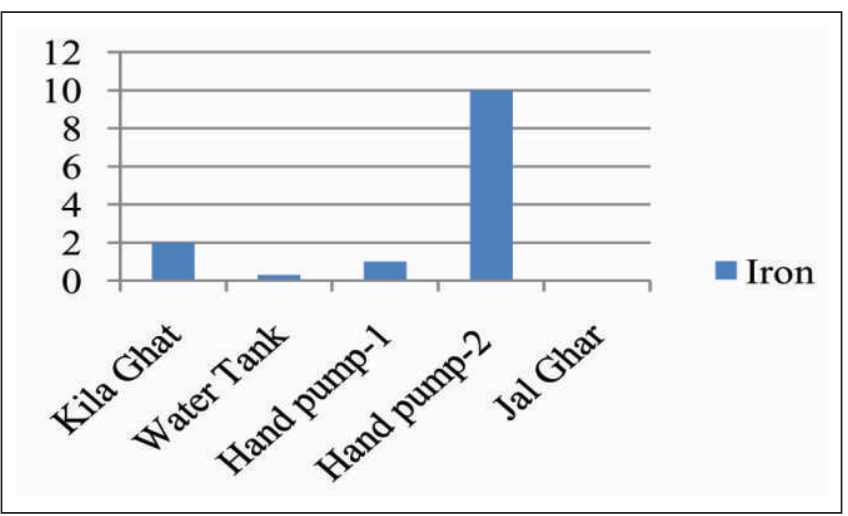

Figure 7: Iron (mg/l)in water samples.

as per drinking water standards (Figure 8, Table1 and Table2). Nitrite

Nitrite in the water samples varies $0.2 \mathrm{mg} / \mathrm{l}$ to $0.5 \mathrm{mg} / \mathrm{l}$. In all the five water samples nitrite is desirable as per drinking water standards (Figure 9, Table1 and Table2).

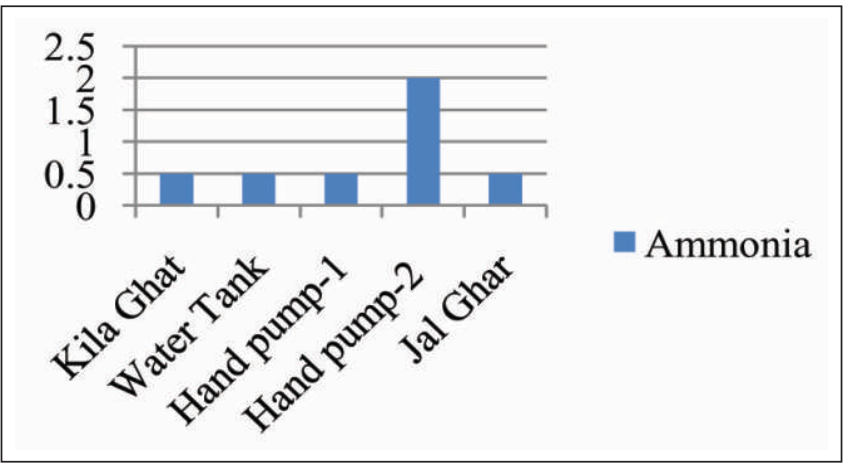

Figure 8: Ammonia (mg/l)in water samples. 


\section{Nitrite}

Nitrite in the water samples varies $0.2 \mathrm{mg} / \mathrm{l}$ to $0.5 \mathrm{mg} / \mathrm{l}$. In all the five water samples nitrite is desirable as per drinking water standards (Figure 9, Table1 and Table2).

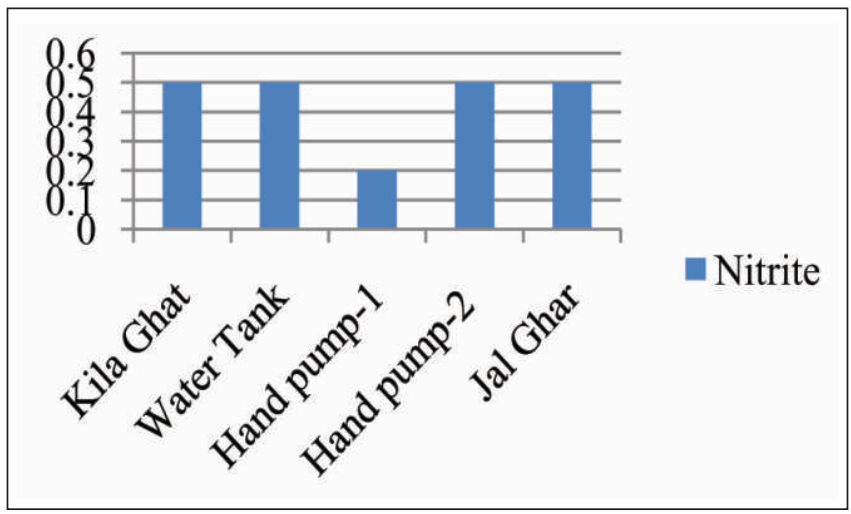

Figure 9: Nitrite(mg/l) in sample locations.

Nitrate

Nitrate in the water samples varies $20 \mathrm{mg} / \mathrm{l}$ to $45 \mathrm{mg} / \mathrm{l}$. In all the five water samples nitrate is desirable as per drinking water standards (Figure 10, Table1 and Table2).

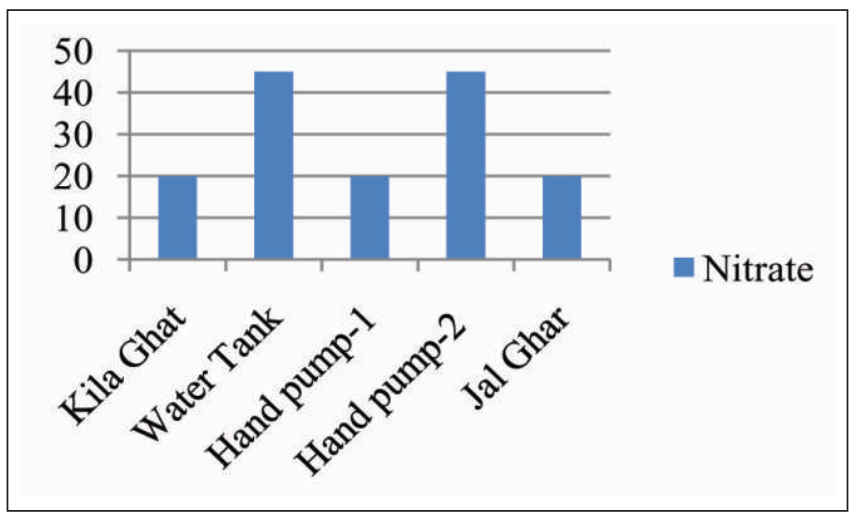

Figure 10: Nitrate (mg/l)in sample locations.

\section{Phosphate}

Phosphate in all the five water samples is nil. In all the five water samples phosphate is desirable as per drinking water standards (Figure 11, Table1 and Table2).

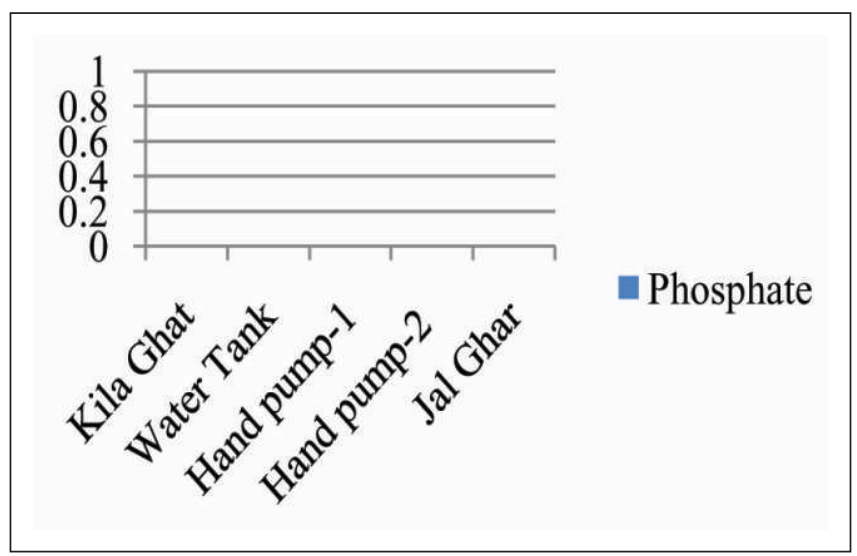

Figure 11: Phosphate (mg/l)inwater samples.

\section{Residual Chlorine}

Residual Chlorine in the water samples varies $0 \mathrm{mg} / \mathrm{l}$ to 0.5 $\mathrm{mg} / \mathrm{l}$. In all the five water samples residual chlorine is desirable as per drinking water standards (Figure 12, Table1 and Table2).

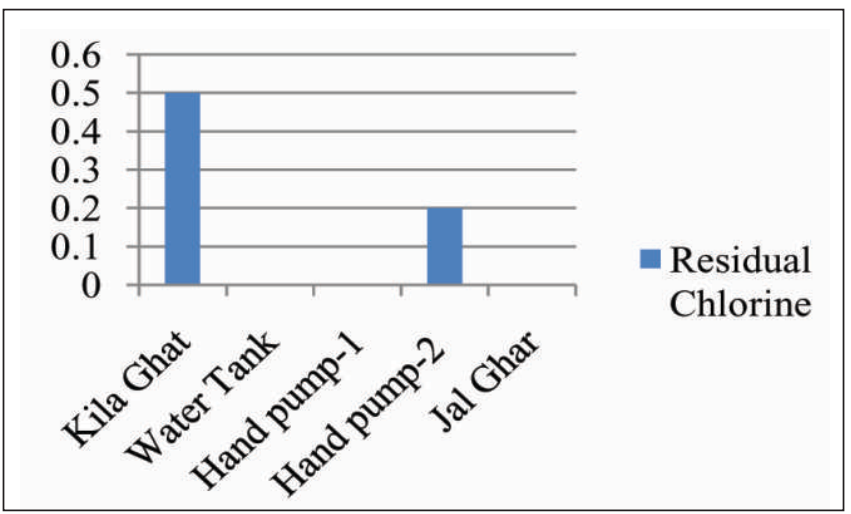

Figure 12: Residual Chlorine (mg/l) at water samples.

\section{CONCLUSIONS}

In the study area water quality is non-potable in water samples Kila Ghat (iron 2 mg/l), Handpump-2 (iron 10 mg/l; ammonia $2 \mathrm{mg} / \mathrm{l}$ ) and potable in water samples Water Tank, Handpump-1, Jal Ghar. The study is highly useful for monitoring the water quality for drinking purpose in the study area.

\section{REFERENCES}

1. Goel, Pooja, Saxena, Abhishek, Singh, Dhruv Sen and Verma, Deepti (2018). Impact of rapid urbanization on water quality index in groundwater fed Gomati River, Lucknow, India, Current Science,114(3): 650-654.

2. Ismail, Alhassan H. (2015). Groundwater Quality Assessment in Urban Area of Baghdad, Iraq, Using Multivariate Statistical Techniques, Eng. \& Tech. Journal,33 (2):463-476.

3. Oiste, A. M. (2014). Groundwater quality assessment in urban environment, Int. J. Environ. Sci. Technol.11:2095-2102.

4. Satyanarayana, P., Appala Raju, N., Harikrishna, K. and Viswanath, K. (2013). Urban Groundwater Quality Assessment: A Case Study Of Greater Visakhapatnam Municipal Corporation Area (Gvmc), Andhra Pradesh, India, International Journal of Engineering Science Invention, 2(5):20-31.

5. Sujatha, M., Gopalakrishnayya, A., Satyanarayana, T. (2012). Assessment Of Groundwater Quality In Rural Areas Of Vijayawada, A.P., International Journal of Engineering Research and Applications ,2 (4):645-648.

6. Wali, S.U., Umar,K.J. , Dankani, I.M. , Abubakar, S.D. , Gada, M.A, , Umar, A. and Usman, A.A. (2018). Groundwater Hydrochemical Characterization in Urban Areas of Southwestern Sokoto Basin Nigeria, SF Journal of Environmental and Earth Science, 1(1):1-17. 